\title{
The age of the palaeodunefield of the northern Murray Basin in South Australia: Preliminary results
}

\author{
C.R. Twidale ${ }^{\mathrm{a}, *}$, J.A. Bourne ${ }^{\mathrm{a}}$, N.A. Spooner ${ }^{\mathrm{b}, 1}$, E.J. Rhodes ${ }^{\mathrm{c}}$ \\ ${ }^{a}$ Geology and Geophysics, School of Earth and Environmental Sciences, The University of Adelaide, Adelaide 5005, SA, Australia \\ ${ }^{\mathrm{b}}$ DSTO, Edinburgh 5111, SA, Australia \\ ${ }^{\mathrm{c}}$ Research School of Earth Sciences and Research School of Pacific and Asian Studies, Australian National University, Canberra, ACT 0200, Australia
}

Available online 8 January 2007

\begin{abstract}
A vast field of old desert dunes extends from northwestern Eyre Peninsula, across Yorke Peninsula and the northern Adelaide Plains into the Murray Basin and northwestern Victoria. There are patches of parabolic forms but the sand ridges under review are of seif, linear or longitudinal type. They trend NW-SE in the west and west-east in the east.

Here, we record luminescence dates for three dune sites in the Waikerie district of the northwestern Murray Basin. They range from, respectively, $151-25.3 \mathrm{ka}, 157-33.3 \mathrm{ka}$, and a basal age of $59.6 \mathrm{ka}$, with sand movement also indicated around 1906 and $1933 \mathrm{CE}$. Apart from the last named, no unconformities are discernible in the sampled sections.
\end{abstract}

(C) 2007 Elsevier Ltd and INQUA. All rights reserved.

\section{Introduction}

It has long been appreciated that although fields of longitudinal or linear desert dunes occupy large areas of the Australian continent, only those of northwestern and central Australia-the Great Sandy Desert and the Simpson Desert sensu lato - are occasionally and discontinuously active. To the south of these active dunefields there are fields of vegetated and stable sand ridges (e.g. Crocker, 1946; David and Browne, 1950, I, pp. 634-635). The palaeodunes (Fig. 1) extend from the eastern margin of the Nullarbor Plain in the west, across much of northern Eyre and Yorke peninsulas (e.g. Crocker, 1946; Jessup, 1967) and the northern Adelaide Plains, and eastwards into the northwestern Murray Basin in South Australia and Victoria (see Lawrence, 1988).

The region is presently semi-arid. Annual average precipitation at Waikerie is $253 \mathrm{~mm}$ distributed throughout the year, although $60 \%$ of the total falls during the period May through October. Winds are predominantly from the

\footnotetext{
${ }^{*}$ Corresponding author. Tel.: + 6188303 5392; fax; +61 883034347 .

E-mail address: rowl.twidale@adelaide.edu.au (C.R. Twidale).

${ }^{1}$ Formerly of Research School of Earth Sciences, Australian National University, Canberra 0200, Australia.
}

southwest quarter. Clearly, the dunes under review are relic from arid environments that no longer obtain in the study area. Moreover, the dunes are of linear type. Their internal structure shows that like their active counterparts in contemporary deserts they formed under the influence of a bidirectional wind regime (McKee and Tibbitts, 1964; Wopfner and Twidale, 1967, 1988). This implies that when the ridges developed the prevalent sand-moving winds (ca. $17 \mathrm{~km} / \mathrm{h}$, but depending on grain size) were from the northwestern and southwestern sectors. Thus, the dunes also are witness to a different wind regime.

Only a few scattered dates have been published pertaining to the Murray Basin dunes (e.g. Gardner et al., 1987). Yet, the ages of these relic dunefields and of the implied arid climatic phase, taken together with the ages of dunefields in central Australia (e.g. Wopfner and Twidale, 1967; Nanson et al., 1992; Twidale et al., 2001; Lomax et al., 2003), would provide information concerning the nature as well as the chronology of geologically recent climatic change at both the regional and global scales (e.g. Hesse et al., 2004). Here, we report luminescence dates for three linear dunes located in the Waikerie Dunefield located in the northwestern Murray Basin, east of the Murray Gorge (Fig. 1c). 

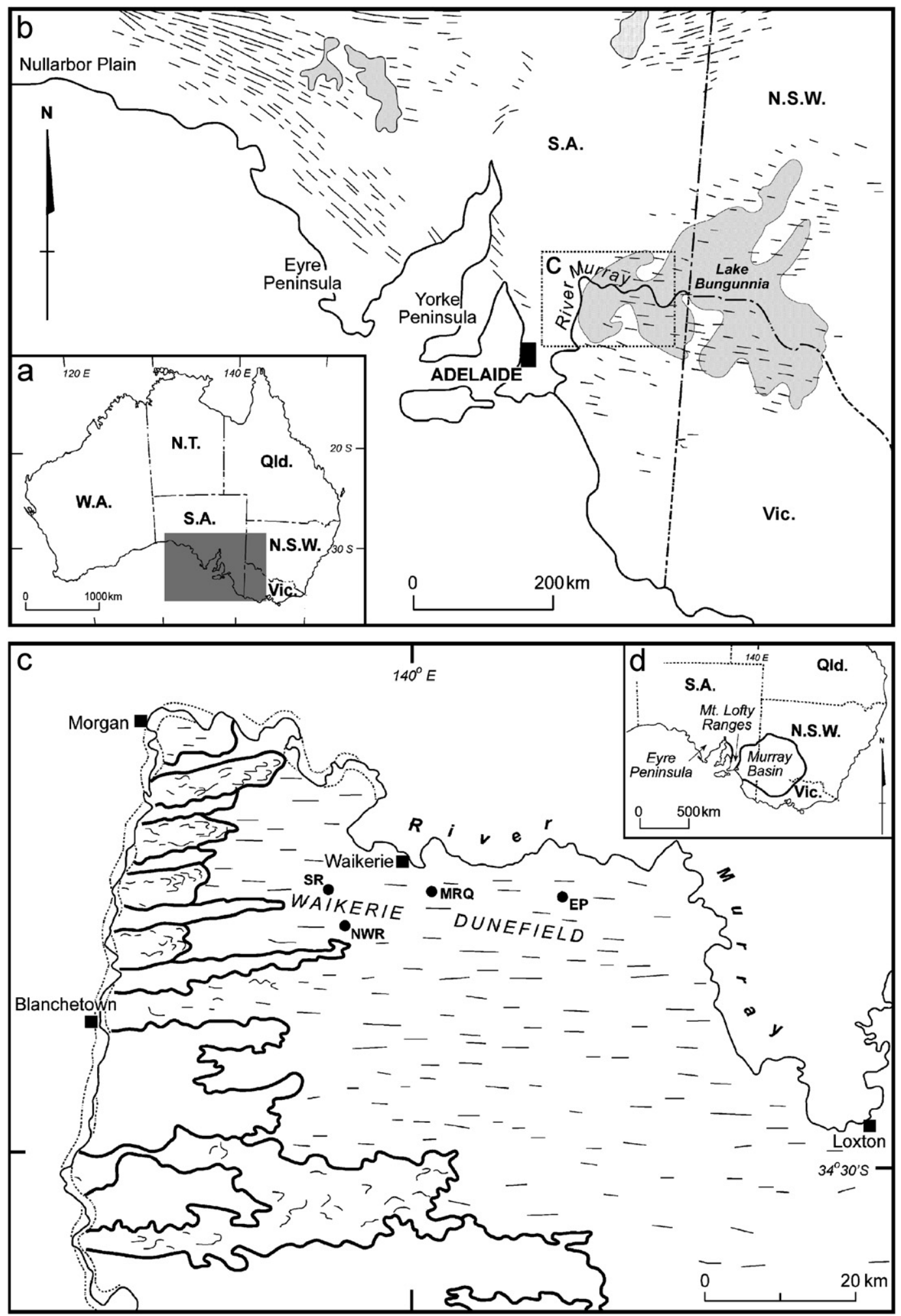

Fig. 1. (a) Location map, (b) map showing the southern Australian palaeodunefield and extent of the former Lake Bungunnia (after Stephenson and Brown, 1989), (c) sample sites (SR, MRQ, EP) from the Waikerie Dunefield. Dotted line outline of Murray Gorge. East and south of the River Murray, wavy lines, parabolic, and irregular dune crests; straight lines, crests of linear or longitudinal dunes. Heavy lines distinguish parabolic dunefields and areas bare of dune sand from the linear dunefield, and (d) extent of Murray Basin and position of Mt Lofty Ranges. 


\section{Geology}

The northern Murray Basin is underlain by a sequence of flat-lying, Late Tertiary sediments resting on a basement of older rocks (Stephenson and Brown, 1989; Rogers, 1995). During the Middle Miocene the region was an embayment of the sea. A thick sequence of calcarenite, the Mannum Limestone, was deposited. During the later Miocene the sea became shallower, and shelly clays and sands were laid down. These conditions extended into the Pliocene and in particular the Loxton and Parilla sands were deposited. These sands merge laterally with estuarine sand and sandy limestone with a thick basal bed of oyster shells known as the Norwest Bend Formation, which occupied the original valley of the lower Murray River. It extended from Tailem Bend in the south, upstream as far as Morgan and beyond, with an eastern arm reaching Overland Corner (Ludbrook, 1961; Stephenson and Brown, 1989). Uplift along the Marmon Jabuk Fault caused the horizontal strata of the basin to be disturbed, and the river to be diverted westwards between Bow Hill and Tailem Bend (Twidale et al., 1978). The shallow Lake Bungunnia (Firman, 1965; Stephenson, 1986) occupied the northwestern part of the Basin some 2.4-0.7 million years ago during Plio-Pleistocene times (Fig. 1b). This uplift impounded Lake Bungunnia in which were deposited the Blanchetown Clay and the Bungunnia Limestone. The termination of the Lake has been attributed to the onset of aridity (An Zhisheng et al., 1986; Stephenson, 1986).

\section{Dunes}

The dunefields of the northern Murray Basin in South Australia, including the Waikerie Dunefield, are quartzitic, trend west-east and form zones some $2 \mathrm{~km}$ wide separated by corridors some $4 \mathrm{~km}$ across. In the latter, calcrete, which gives rise to typical karst forms and particularly sinkholes (e.g. Weatherby, 1974), is exposed. At their western extremity, the dunefields appear to originate in the slipoff slopes of the meanders described by the Murray River on the valley floor. Here, and extending for several kilometres along the length of the fields, parabolic dunes are dominant. Downwind, however, they develop into longitudinal sand ridges. Geological and morphological evidence suggest that whatever their morphology, the dunefields of the northwestern Murray Basin postdate the Middle Pleistocene. The surface over which the dunefields extend carries a partial cover of various Pliocene and Early and Middle Pleistocene riverine and lacustrine strata. An Zhisheng et al. (1986) date the onset of aridity at about 0.5 million years ago.

\section{Field sampling}

Though establishing the age of the sand, and hence of dune building, was the primary objective, sampling sites were selected in the Waikerie Dunefield with more than this in mind. From a practical point of view, sites readily accessible to a backhoe were selected so as to save time and hence money. Sites where either field or borelog evidence indicated the possibility of reaching dune base without unduly deep excavations were also preferred. The dunefield comprises several dunes running west-east roughly in parallel and sample sites were chosen along the length of the dunefield in an attempt to obtain dates that would indicate the rate of dune advance.

Sampling from trenches cut by backhoe was preferred to augering. The internal structure of a dune can be seen in a trench and samples selected accordingly. The disadvantage of trenching, apart from cost in time and money, is that some of the reddish dune sands of the northern Murray Basin, including those sampled and discussed here, lack fines and are unstable, making this collection method potentially dangerous.

\section{Luminescence dating procedures}

\subsection{Sample collection and preparation}

Sediment samples were collected using steel coring tubes driven into the freshly exposed section faces. Each core tube contained sufficient sediment for extraction of quartz grains for luminescence analysis, and also for in situ water content measurement and laboratory assay of radioisotope (U, Th, and K) concentrations. Sand-sized quartz grains were extracted from each sediment sample in the laboratory under low-intensity red light in a procedure including sequential $\mathrm{HCl}$ acid digestion, dry sieving, heavy liquid flotation (collecting $<2.68 \mathrm{~g} \mathrm{~cm}^{-3}$ fraction), and etching in $48 \%$ HF acid for $40 \mathrm{~min}$. OSL measurements were performed on approximately $5-6 \mathrm{mg}$ of etched quartz attached by silicone oil to the central part of stainless steel discs.

\subsection{Palaeodose measurement}

OSL measurements were made using one of two methods. For samples $\mathrm{ANU}_{\mathrm{OD}} 1413, \mathrm{ANU}_{\mathrm{OD}} 1414$, and $\mathrm{ANU}_{\mathrm{OD}} 1415$, palaeodoses were determined using the "Australian slide" method (Prescott et al., 1993), with a linear plus single saturating exponential curve fitted (scale factor $=1.00)$ to additive and regenerative dose growth curves containing 64 sample discs each. (Further details of this method may be found in Spooner et al., 2001.) An Elsec Type 9010 automated reader with $500 \pm 80 \mathrm{~nm}$ stimulation, and UV emissions detected by an EMI 9235QA photomultiplier tube was used for OSL measurement, which was performed at $19^{\circ} \mathrm{C}$. Irradiations were by a ${ }^{90} \mathrm{Sr} /{ }^{90} \mathrm{Y} \beta$ source housed in an Elsec Type 9022 irradiator, and followed by preheating to $220^{\circ} \mathrm{C}$ for $300 \mathrm{~s}$ prior to each OSL measurement.

For samples $\mathrm{ANU}_{\mathrm{OD}} 1584, \mathrm{ANU}_{\mathrm{OD}} 1585, \mathrm{ANU}_{\mathrm{OD}} 1586$, $\mathrm{ANU}_{\mathrm{OD}} 1587, \mathrm{ANU}_{\mathrm{OD}} 1588, \mathrm{ANU}_{\mathrm{OD}} 1589$, and $\mathrm{AN}-$ $\mathrm{U}_{\mathrm{OD}} 1600$, palaeodoses were determined using the single 
aliquot regenerative-dose (SAR) protocol of Murray and Wintle (2000). OSL measurements were made using an automated Risø TL-DA-15 fitted with a filtered halogen lamp providing blue-green stimulation between 420 and $560 \mathrm{~nm}$, and with an inbuilt ${ }^{90} \mathrm{Sr} /{ }^{90} \mathrm{Y} \beta$ irradiation source. UV emissions were filtered using $7.5 \mathrm{~mm}$ of Hoya U340 glass filter and detected with a 9235QA photomultiplier tube. OSL measurement was performed at $125^{\circ} \mathrm{C}$; natural and regenerative OSL measurements were preceded by a preheat treatment of $260^{\circ} \mathrm{C}$ for $10 \mathrm{~s}$, while OSL sensitivity measurements were preceded by a treatment of $220^{\circ} \mathrm{C}$ for $10 \mathrm{~s}$. We note that recent comparisons between the two optical dating methods used have shown good agreement for Australian quartz (e.g. Bowler et al., 2003), including samples which were measured using both methods using exactly the equipment and methods described above.

\subsection{Dose-rate determination and age evaluation}

The $\gamma$ ray intensity was measured in situ for each sample using a field gamma spectrometer, and $\mathrm{U}$, Th, and $\mathrm{K}$ concentrations were derived from these data. $\mathrm{U}, \mathrm{Th}$, and $\mathrm{K}$ concentrations were also measured on sediment splits, using instrumental neutron activation analysis (INAA) for $\mathrm{U}$, and delayed neutron activation (DNA) for Th and K, performed by Becquerel Laboratories, Lucas Heights Science and Technology Centre (jobs \#01475 and 03358). The weighted means of the INAA/DNA data and the $\gamma$ scintillometry data were used as the soil radioisotope concentrations. The internal activities of the quartz grains were assumed to be $10 \%$ of the total activity, based on Aitken (1985), and the efficiency with which internal $\alpha$ particle irradiation-induced OSL was assumed to be $a=0.043 \pm 0.01$, following Questiaux (1991) and Thorne et al. (1999). In situ water content was measured from the sediment collected in the coring tubes. Cosmic ray dose rates were calculated using the data of Prescott and Hutton (1994), taking into account increasing attenuation by an assumed stepwise accumulation of overburden. Sample dose rates and ages were calculated using the AGE program of Grün (1999), incorporating the dose-rate conversion factors of Adamiec and Aitken (1998), and are presented in Table 1.

\section{Results}

Three dunes have been sampled and dated-that exposed on 'Shed Road', the Loxton and Waikerie Council sand quarry, and the ridge on the eastern side of West Boundary Road near the 'Eremophila Park' homestead. All are in the Waikerie area and from what has been termed the Waikerie Dunefield (Figs. 1c and 2).

\subsection{Shed Road}

The Shed Road sampling site standing about $40 \mathrm{~m}$ above sea level is in an old roadside sand pit located some $10 \mathrm{~km}$ WSW of Waikerie $\left(13^{\circ} 392^{\prime} \mathrm{S} ; 139^{\circ} 53.545^{\prime} \mathrm{E}\right)$. The existing irregular face was cut back 1 or $2 \mathrm{~m}$ and extended down to a depth of $7.6 \mathrm{~m}$ below the local dune surface. Samples SR730 (ANU OD 1586), SR480 (ANU OD 1585), and SR400 $\left(\mathrm{ANU}_{\mathrm{OD}} 1584\right)$, at $7.3,4.8$, and $4 \mathrm{~m}$ below the local dune surface, gave dates of $151 \pm 13,103 \pm 8$, and $25.3 \pm 2.4 \mathrm{ka}$, respectively (Fig. 2).

\subsection{Maggea Road quarry}

The Loxton and Waikerie District Council has an open sand pit east of the Maggea Road (MRQ) $\left(34^{\circ} 12.71^{\prime} \mathrm{S}\right.$; $\left.140^{\circ} 01.25^{\prime} \mathrm{E}\right)$. Late Tertiary sandstone was exposed in the

Table 1

Ages for each sample, along with the analytical and environmental data, and calculated dose-rates

\begin{tabular}{|c|c|c|c|c|c|c|c|c|c|c|c|c|c|c|c|c|c|c|c|c|c|c|c|c|c|c|c|}
\hline \multirow{2}{*}{$\begin{array}{l}\text { Field code } \\
\text { ANU code } \\
\text { Altitude }(\mathrm{m}) \\
\text { Burial depth }(\mathrm{m})\end{array}$} & \multirow{2}{*}{\multicolumn{3}{|c|}{$\begin{array}{c}\text { MRQ0.94 } \\
\mathrm{ANU}_{\mathrm{OD}} 1413 \\
59 \\
0.94\end{array}$}} & \multirow{2}{*}{\multicolumn{3}{|c|}{$\begin{array}{c}\text { MRQ3.08 } \\
\text { ANU }_{\mathrm{OD}} 1414 \\
57 \\
3.08\end{array}$}} & \multirow{2}{*}{\multicolumn{3}{|c|}{$\begin{array}{c}\text { MRQ4.90 } \\
\text { ANU }_{\mathrm{OD}} 1415 \\
55 \\
4.90\end{array}$}} & \multirow{2}{*}{\multicolumn{3}{|c|}{$\begin{array}{c}\text { SR400 } \\
\text { ANU }_{\text {OD }} 1584 \\
\text { Approx. } 40 \\
4.0\end{array}$}} & \multirow{2}{*}{\multicolumn{3}{|c|}{$\begin{array}{c}\mathrm{SR} 480 \\
\text { ANU }_{\mathrm{OD}} 1585 \\
\text { approx. } 40 \\
4.8\end{array}$}} & \multirow{2}{*}{\multicolumn{3}{|c|}{$\begin{array}{c}\text { SR730 } \\
\text { ANU }_{\text {OD }} 1586 \\
\text { approx. } 40 \\
7.3\end{array}$}} & \multicolumn{3}{|c|}{$\begin{array}{c}\mathrm{EP} 050 \\
\mathrm{ANU}_{\mathrm{OD}} 1587 \\
100\end{array}$} & \multicolumn{3}{|c|}{$\begin{array}{c}\mathrm{EP} 100 \\
\mathrm{ANU}_{\mathrm{OD}} 1588 \\
100\end{array}$} & \multicolumn{3}{|c|}{$\begin{array}{c}\text { EP310 } \\
\text { ANU }_{\text {OD }} 1600 \\
100\end{array}$} \\
\hline & & & & & & & & & & & & & & & & & & & 0.50 & \pm & 0.25 & 1.00 & \pm & 0.25 & 3.10 & \pm & 0.25 \\
\hline alaeodose (Gy) & .1 & \pm & 5.7 & .7 & \pm & 5.0 & 163.8 & \pm & 14.9 & 34.4 & \pm & 1.7 & 23.0 & \pm & 4.0 & 83.0 & \pm & 7.0 & 0.061 & \pm & 0.004 & 0.074 & \pm & 0.003 & 56.7 & \pm & 2.1 \\
\hline Water & & \pm & 0.1 & 1.8 & \pm & 0.1 & 4.3 & \pm & 0.2 & 1.8 & \pm & 0.1 & 5 & \pm & 0.1 & .7 & \pm & 1 & 5.0 & \pm & 5.0 & 5.0 & \pm & 5.0 & 5.0 & \pm & 5.0 \\
\hline Grain size $(\mu \mathrm{m})$ & 107.5 & \pm & 17.5 & 107.5 & \pm & 17.5 & 107.5 & \pm & 17.5 & 107.5 & \pm & 17.5 & 107.5 & \pm & 17.5 & 107.5 & \pm & 17.5 & 152.5 & \pm & 27.5 & 152.5 & \pm & 27.5 & 152.5 & \pm & 27.5 \\
\hline \multicolumn{28}{|l|}{$I N A A$} \\
\hline $\mathrm{U}(\mathrm{ppm})$ & 0.26 & \pm & 0.08 & 0.23 & \pm & 0.08 & 0.36 & \pm & 0.08 & 0.71 & \pm & 0.13 & 0.51 & \pm & 0.11 & 0.54 & \pm & 0.11 & 0.20 & \pm & 0.08 & 0.21 & \pm & 0.08 & 0.33 & \pm & 0.08 \\
\hline \multicolumn{28}{|l|}{$D N A$} \\
\hline Th (ppn & 1.84 & \pm & 0.06 & 2.40 & \pm & 0.07 & 2.34 & \pm & 0.07 & 3.47 & \pm & 0.09 & 2.63 & \pm & 0.08 & 3.02 & \pm & 0.08 & 1.33 & \pm & 0.05 & 1.36 & \pm & 0.05 & 2.31 & \pm & 0.07 \\
\hline $\mathrm{K}(\%)$ & 0.68 & \pm & 0.06 & 0.63 & \pm & 0.06 & 0.83 & \pm & 0.07 & 0.89 & \pm & 0.07 & 0.78 & \pm & 0.06 & 0.79 & \pm & 0.06 & 0.55 & \pm & 0.05 & 0.44 & \pm & 0.05 & 0.60 & \pm & 0.05 \\
\hline \multicolumn{28}{|l|}{ In situ NaI $\gamma$-scintillometry } \\
\hline $\mathrm{U}(\mathrm{ppm})$ & 39 & \pm & 0.03 & 0.39 & \pm & 0.04 & 0.51 & \pm & 0.04 & $\mathrm{~N} / \mathrm{A}$ & & $\mathrm{N} / \mathrm{A}$ & $\mathrm{N} / \mathrm{A}$ & & $\mathrm{N} / \mathrm{A}$ & $\mathrm{N} / \mathrm{A}$ & & $\mathrm{N} / \mathrm{A}$ & $\mathrm{N} / \mathrm{A}$ & & $\mathrm{N} / \mathrm{A}$ & $\mathrm{N} / \mathrm{A}$ & & $\mathrm{N} / \mathrm{A}$ & $\mathrm{N} / \mathrm{A}$ & & $\mathrm{N} / \mathrm{A}$ \\
\hline Th ( & 2.03 & \pm & 0.07 & 2.42 & \pm & 0.08 & 2.31 & \pm & 0.07 & $\mathrm{~N} / \mathrm{A}$ & & $\mathrm{N} / \mathrm{A}$ & $\mathrm{N} / \mathrm{A}$ & & $\mathrm{N} / \mathrm{A}$ & $\mathrm{N} / \mathrm{A}$ & & $\mathrm{N} / \mathrm{A}$ & $\mathrm{N} / \mathrm{A}$ & & $\mathrm{N} / \mathrm{A}$ & $\mathrm{N} / \mathrm{A}$ & & $\mathrm{N} / \mathrm{A}$ & $\mathrm{N} / \mathrm{A}$ & & $\mathrm{N} / \mathrm{A}$ \\
\hline $\mathrm{K}(\%)$ & 0.56 & \pm & 0.01 & 0.60 & \pm & 0.01 & 0.62 & \pm & 0.01 & $\mathrm{~N} / \mathrm{A}$ & & $\mathrm{N} / \mathrm{A}$ & $\mathrm{N} / \mathrm{A}$ & & $\mathrm{N} / \mathrm{A}$ & $\mathrm{N} / \mathrm{A}$ & & $\mathrm{N} / \mathrm{A}$ & $\mathrm{N} / \mathrm{A}$ & & $\mathrm{N} / \mathrm{A}$ & $\mathrm{N} / \mathrm{A}$ & & $\mathrm{N} / \mathrm{A}$ & $\mathrm{N} / \mathrm{A}$ & & $\mathrm{N} / \mathrm{A}$ \\
\hline \multicolumn{28}{|c|}{ Isotope concentration weighted mean } \\
\hline $\mathrm{U}(\mathrm{ppm})$ & 0.37 & \pm & 0.03 & 0.36 & \pm & 0.04 & 0.48 & \pm & 0.04 & $\mathrm{~N} / \mathrm{A}$ & & $\mathrm{N} / \mathrm{A}$ & $\mathrm{N} / \mathrm{A}$ & & $\mathrm{N} / \mathrm{A}$ & $\mathrm{N} / \mathrm{A}$ & & $\mathrm{N} / \mathrm{A}$ & $\mathrm{N} / \mathrm{A}$ & & $\mathrm{N} / \mathrm{A}$ & $\mathrm{N} / \mathrm{A}$ & & $\mathrm{N} / \mathrm{A}$ & $\mathrm{N} / \mathrm{A}$ & & $\mathrm{N} / \mathrm{A}$ \\
\hline Th (ppn & 1.92 & \pm & 0.05 & 2.41 & \pm & 0.05 & 2.33 & \pm & 0.05 & $\mathrm{~N} / \mathrm{A}$ & & N/A & $\mathrm{N} / \mathrm{A}$ & & $\mathrm{N} / \mathrm{A}$ & $\mathrm{N} / \mathrm{A}$ & & $\mathrm{N} / \mathrm{A}$ & $\mathrm{N} / \mathrm{A}$ & & $\mathrm{N} / \mathrm{A}$ & $\mathrm{N} / \mathrm{A}$ & & $\mathrm{N} / \mathrm{A}$ & $\mathrm{N} / \mathrm{A}$ & & $\mathrm{N} / \mathrm{A}$ \\
\hline $\mathrm{K}(\%)$ & 0.56 & \pm & 0.01 & 0.60 & \pm & 0.01 & 0.62 & \pm & 0.01 & $\mathrm{~N} / \mathrm{A}$ & & $\mathrm{N} / \mathrm{A}$ & $\mathrm{N} / \mathrm{A}$ & & $\mathrm{N} / \mathrm{A}$ & $\mathrm{N} / \mathrm{A}$ & & $\mathrm{N} / \mathrm{A}$ & $\mathrm{N} / \mathrm{A}$ & & $\mathrm{N} / \mathrm{A}$ & $\mathrm{N} / \mathrm{A}$ & & $\mathrm{N} / \mathrm{A}$ & N/A & & $\mathrm{N} / \mathrm{A}$ \\
\hline Cosmic & 0.19 & \pm & 0.03 & 0.17 & \pm & 0.02 & 0.15 & \pm & 0.02 & 0.13 & \pm & 0.02 & 0.16 & \pm & 0.03 & 0.14 & \pm & 0.03 & 0.20 & \pm & 0.02 & 0.19 & \pm & 0.02 & 0.15 & \pm & 0.02 \\
\hline Total & 0.99 & $\overline{ \pm}$ & 0.03 & 1.04 & $\overline{ \pm}$ & 0.03 & 1.04 & \pm & 0.03 & 1.36 & \pm & 0.11 & 1.20 & $\overline{ \pm}$ & 0.09 & 1.22 & $\overline{ \pm}$ & 0.09 & 0.86 & $\overline{ \pm}$ & 0.07 & 0.75 & $\overline{ \pm}$ & 0.06 & 0.95 & \pm & 0.07 \\
\hline Age (ka) & 33.3 & \pm & 5.8 & 95.3 & \pm & 5.8 & 157 & \pm & 15 & 25.3 & \pm & 2.4 & 103 & \pm & 8 & 151 & \pm & 13 & 0.071 & \pm & 0.007 & 0.098 & \pm & 0.009 & 59.6 & \pm & 5.0 \\
\hline
\end{tabular}




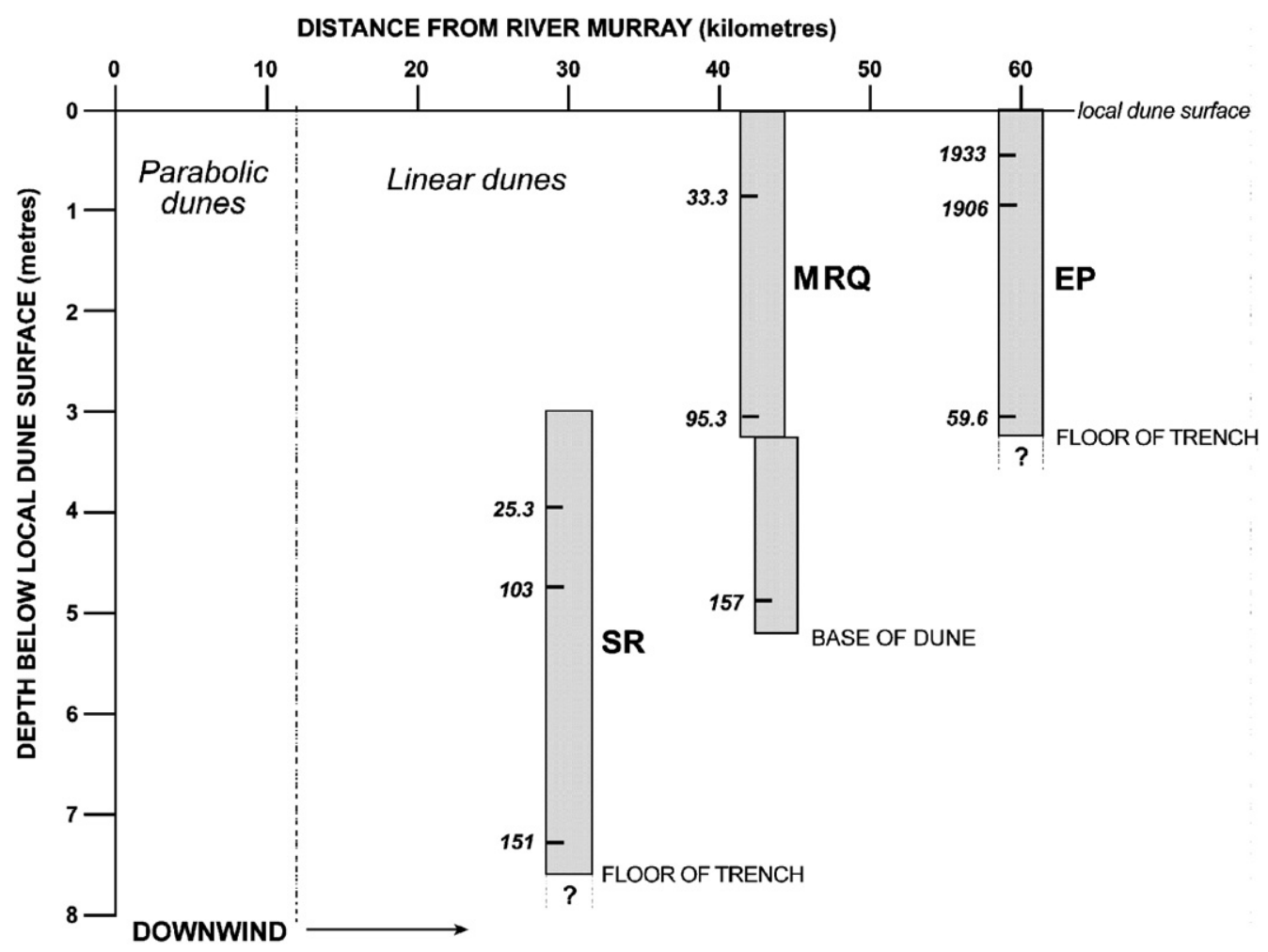

Fig. 2. Spatial relationship of sample sites and comparative depth of sampled sections from the Waikerie Dunefield. Numbers indicate age of sands at that position, displayed in thousands of years (except for 1906 and 1933 which refer to years CE).

sloping floor of the quarry. The quarry face was scraped and cleaned and a pit excavated in the quarry floor to expose the base of the dune adjacent to the prepared face, some $5.2 \mathrm{~m}$ below the dune crest. One sample MRQ490 $\left(\mathrm{ANU}_{\mathrm{OD}} 1415\right)$ was taken $4.9 \mathrm{~m}$ below the local dune surface and just above the base of the dune, another MRQ308 (ANU $\left.{ }_{\mathrm{OD}} 1414\right)$ at $3.08 \mathrm{~m}$ below the local dune surface, and one about a metre below the crest MRQ094

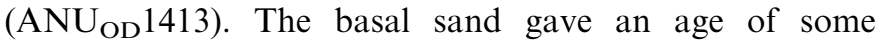
$157 \pm 15 \mathrm{ka}$, the intermediate sample $95.3 \pm 5.8 \mathrm{ka}$, and the shallowest $33.3 \pm 5.8 \mathrm{ka}$.

\subsection{Vicinity of 'Eremophila Park'}

A dune near the 'Eremophila Park' homestead (EP), on West Boundary Road, was selected for excavation $\left(34^{\circ} 12.89^{\prime} \mathrm{S} ; 140^{\circ} 11.14^{\prime} \mathrm{E}\right)$. A pit was dug to a depth of $3.3 \mathrm{~m}$ below the surface to a bleached basal zone that might have indicated proximity to the base of the dune. But no definite substrate rock was exposed and practical considerations concerned with safety (slumping of sand) prevented deeper excavation. The deepest layer of sand EP310 (ANU OD 1600) sampled at $3.1 \mathrm{~m}$ below the local dune surface gave a date of $59.6 \pm 5 \mathrm{ka}$. An intermediate sample EP160 (ANU $\left.{ }_{\mathrm{OD}} 1589\right), 1.6 \mathrm{~m}$ below the local dune surface, proved to be bioturbated and produced no useful date (hence its omission from Table 1), though it is likely that the depositional age lies in the range of 9-32 ka. In addition, excavation revealed two layers of sand on the flank of the dune, brown in colour, in contrast with the reddish colour of the main dune. Each is rich in organic material indicative of a former vegetational ground cover. Each meets the dune sand in a sharp discontinuity. Samples EP100 (ANU OD $^{1588)}$ and EP050 (ANU $\left.{ }_{\mathrm{OD}} 1587\right)$ from each of these layers, a metre and the other half a metre below the local dune surface, respectively, gave dates of CE $1906 \pm 9$ years and CE $1933 \pm 7$ years.

\section{Discussion}

Apart from the recent layers of brown sand on the flank of the 'Eremophila Park' dune, no breaks in the sedimentary record, as indicated by colour or compositional change or truncated cross bedding, were exposed within the dunes. Long periods of desert conditions appear to be implied (see also Stokes et al., 1998). However, appearances may be deceptive and disconformities may be veiled by weathering. Also, the slow implied rates of deposition are explicable in terms of periods of dynamic equilibrium with crestal erosion balanced by deposition. Closer sampling strategies applied in more recent investigations may provide a sequence of dates that will resolve the problem (Lomax et al., 2006).

The few dates reported here suggest that dune building began in the northwestern Murray Basin during the Middle Pleistocene. So far as age range is concerned there is a reasonable correspondence between the Shed Road and Maggea Road quarry dune sites. Nor is the 'Eremophila 
Park' dune ridge incompatible with them, for the base of the dune may not have been reached by the backhoe.

The dates of the basal samples from the SR and MRQ sites contrast with a $125 \mathrm{ka}$ estimate obtained (D. Beng, pers. comm., 2000) from the base of a dune exposed in a coastal cliff near Port Hughes, northwestern Yorke Peninsula, which, like others on the opposed coast of northeastern Eyre Peninsula extends below present sea level (Jessup, 1967; Van Deur, 1983). No equivalent of the $4 \mathrm{ka}$ period of dune development, which is evidenced in the Gawler Ranges (Campbell et al., 1996), has been identified so far in the Murray Basin. The 59.6 ka date of the earliest sample from the 'Eremophila Park' dune coincides with a 'lake-full' stage at Lake Mungo (Bowler et al., 2003).

If indicative of regional climatic conditions the dune developments discussed here show that aridity prevailed when indigenous people entered the area about $40 \mathrm{ka}$ (Bowler, 1998; Bowler and Price, 1998; Thorne et al., 1999; Bowler et al., 2003). A much older phase of dune building is in evidence in the Waikerie Dunefield than noted in other palaeodesert regions in the southern hemisphere (e.g. Stokes et al., 1998; Munyikwa, 2005). The dates reported here can be construed as correlating with their periods of aeolian deposition, but pauses in dune building noted by them are not in evidence in the Waikerie Dunefield. The recent sand movements of around 1906 and 1933 evidenced at the 'Eremophila Park' dune site could reflect drought, fire or land clearance.

\section{Acknowledgements}

The writers acknowledge with thanks financial support from University of Adelaide Small Research Grants in 2001-2002. We thank Ric Noble, of the Loxton-Waikerie District Council, who provided invaluable local knowledge and interest in our survey; R.J. Mills and Robert Cain who excavated the sites and proffered sound advice and muscle; Norman Hill, RSES, for sample preparation; Daniele Questiaux for assistance with data analysis; and Dr N. Lancaster, Dr Jeffrey Knott and an anonymous reviewer, for helpful suggestions.

\section{References}

Adamiec, G., Aitken, M.J., 1998. Dose-rate conversion factors: update. Ancient TL 16 (2), 37-50.

Aitken, M.J., 1985. Thermoluminescence Dating. Academic Press, London, 359pp.

An Zhisheng, Bowler, J.M., Opdyke, N.D., Macumber, P.G., Firman, J.B., 1986. Palaeomagnetic stratigraphy of Lake Bungunnia: PlioPleistocene precursor of aridity in the Murray Basin, southeastern Australia. Palaeogeography, Palaeoclimatology, Palaeoecology 54, 219-239.

Bowler, J.M., 1998. Willandra lakes revisited: environmental framework for human occupation. Archaeology in Oceania 33, 120-155.

Bowler, J.M., Price, D.M., 1998. Luminescence dates and stratigraphic analyses at Lake Mungo: review and new perspectives. Archaeology in Oceania 33, 156-168.
Bowler, J., Johnston, H., Olley, J.M., Prescott, J.R., Roberts, R.G., Shawcross, W., Spooner, N., 2003. New ages for human occupation and climatic change at Lake Mungo, Australia. Nature 421, 837-840.

Campbell, E.M., Twidale, C.R., Hutton, J.T., Prescott, J.R., 1996. Preliminary investigations of dunes of the Gawler Ranges Province, South Australia. Transactions of the Royal Society of South Australia 120, 21-36.

Crocker, R.L., 1946. Post-Miocene climatic and geologic history and its significance in relation to the genesis of the major soil types of South Australia. Council for Scientific and Industrial Research Bulletin 193, $56 \mathrm{pp}$.

David, T.W.E., Browne, W.R., 1950. Geology of the Commonwealth of Australia. Arnold, London, 3 volumes.

Firman, J.B., 1965. Late Cainozoic lacustrine deposits in the Murray Basin, South Australlia. Geological Survey of South Australia, Quarterly Geological Notes 16, 1-2.

Gardner, G.J., Mortlock, A.J., Price, D.M., Readhead, M.L., Wasson, R.J., 1987. Thermoluminescence and radiocarbon dating of Australian desert dunes. Australian Journal of Earth Sciences 34 (3), 343-357.

Grün, R., 1999. Age calculation. Unpublished computer program, Australian National University, Australia.

Hesse, P.P., Magee, J.W., van der Kaars, S., 2004. Late Quaternary climates of the Australian arid zone: a review. Quaternary International 118-119, 87-102.

Jessup, R.W., 1967. The Late-Quaternary eustatic and geologic history of northern Yorke Peninsula. South Australia. In: Morrison, R.B., Wright, H.E. (Eds.), Means of Correlation of Quaternary Successions. vol. 5. Proceedings of the VII Congress INQUA. University of Utah Press, Salt Lake City, pp. 395-406.

Lawrence, C.R., 1988. Murray Basin. In: Douglas, J.G., Ferguson, J.A. (Eds.), Geology of Victoria. Geological Society of Australia. Victorian Division, Melbourne, pp. 352-363.

Lomax, J., Hilgers, A., Twidale, C.R., Bourne, J.A., Radtke, U., 2006. Treatment of broad palaeodose distributions in OSL dating of dune sands from the western Murray Basin, South Australia. Quaternary Geochronology, doi:10.1016/j.quageo.2006.05.015.

Lomax, J., Hilgers, A., Wopfner, H., Grün, R., Twidale, C.R., Radtke, U., 2003. The onset of dune formation in the Strzelecki Desert, South Australia. Quaternary Science Reviews 22 (10-13), 1067-1076.

Ludbrook, N.H., 1961. Stratigraphy of the Murray Basin in South Australia Geological Survey of South Australia. Bulletin 36, 96pp.

McKee, E.D., Tibbitts, G.C., 1964. Primary structures in a seif dune and associated deposits in Libya. Journal of Sedimentary Petrology 34, $5-17$.

Munyikwa, K., 2005. Synchrony of southern hemisphere Late Pleistocene arid episodes: a review of luminescence chronologies from arid aeolian landscapes south of the Equator. Quaternary Science Reviews 24, 2555-2583.

Murray, A.S., Wintle, A.G., 2000. Luminescence dating of quartz using an improved single-aliquot regenerative-dose protocol. Radiation Measurements 32, 57-73.

Nanson, G.C., Chen, X.Y., Price, D.M., 1992. Lateral migration, thermoluminescence chronology and colour variation of longitudinal dunes near Birdsville in the Simpson Desert, central Australia. Earth Surface Processes and Landforms 17, 807-819.

Prescott, J.R., Hutton, J.T., 1994. Cosmic ray contributions to dose-rates for luminescence and ESR dating: large depths and long-term time variations. Radiation Measurements 23 (2/3), 497-500.

Prescott, J.R., Huntley, D.J., Hutton, J.T., 1993. Estimation of equivalent dose in thermoluminescence dating - the Australian slide method. Ancient TL 11 (1), 1-5.

Questiaux, D.G., 1991. Optical dating of loess: comparisons between different grain size fractions for infrared and green excitation wavelengths. Nuclear Tracks and Radiation Measurements $18(1 / 2)$, 133-139.

Rogers, P.A., 1995. Continental sediments of the Murray Basin. In: Drexel, J.F., Preiss, W.V. (Eds.), The Geology of South Australia, vol. 
2. The Phanerozoic. Geological Survey of South Australia Bulletin 54, pp. 252-254.

Spooner, N.A., Olley, J.M., Questiaux, D.G., Chen, X.Y., 2001. Optical dating of an aeolian deposit on the Murrumbidgee floodplains. Quaternary Science Reviews (Quaternary Geochronology) 20, 835-840.

Stephenson, A.E., 1986. Lake Bungunnia - a Plio-Pleistocene megalake in southern Australia. Palaeogeography, Palaeoclimatology, Palaeoecology $57,137-156$.

Stephenson, A.E., Brown, C.M., 1989. The ancient Murray River system. B.M.R. Journal of Australian Geology and Geophysics 11, 387-395.

Stokes, S., Haynes, G., Thomas, D.S.G., Horrocks, J.L., Higginson, M., Malifa, M., 1998. Punctuated aridity in southern Africa during the last glacial cycle: the chronology of linear dune construction in the northeastern Kalahari. Palaeogeography, Palaeoclimatology, Palaeoecology 137, 305-322.

Thorne, A., Grun, R., Mortimer, G., Spooner, N.A., Simpson, J., McCulloch, M., Taylor, L., Curnoe, D., 1999. Australia's oldest human remains: age of the Lake Mungo 3 skeleton. Journal of Human Evolution 36, 591-612.

Twidale, C.R., Lindsay, J.M., Bourne, J.A., 1978. Age and origin of the Murray River and Gorge in South Australia. Proceedings of the Royal Society of Victoria 90, 27-42.

Twidale, C.R., Prescott, J.R., Bourne, J.A., Williams, F.M., 2001. Age of desert dunes near Birdsville, southwest Queensland. Quaternary Science Reviews 20, 1355-1364.

Van Deur, W.J., 1983. Submerged dunes of northeastern Eyre Peninsula. Unpublished M.A. Thesis, University of Adelaide, Adelaide, $115 \mathrm{pp}$.

Weatherby, K., 1974. The Myrla sinkholes. Geological Survey of South Australia Quarterly Geological Notes 50, 9-12.

Wopfner, H., Twidale, C.R., 1967. Geomorphological History of the Lake Eyre Basin. In: Jennings, J.N., Mabbutt, J.A. (Eds.), Landform Studies from Australia and New Guinea. Australian National University Press, Canberra, pp. 117-143 (Chapter 7).

Wopfner, H., Twidale, C.R., 1988. Formation and age of desert dunes in the Lake Eyre depocentres in central Australia. Geologische Rundschau 77, 815-834. 